Simon Gelman MD PH D, Jorge E. Rivas MD, Hamdi Erdemir MD, Suzanne Oparil MD, James Proctor, Thomas MacKrell MD, Lloyd Smith MA

\title{
Hormonal and haemodynamic responses to upper abdominal surgery during isoflurane and balanced anaesthesia
}

The purpose of the study was to compare the protective role of different anaesthetic techniques against surgicat stress. Sixty patients undergoing elective laparotomy were randomly divided into six groups of ten patients each: Group I was given 0.65 MAC nitrous oxide (66 per cent inspired) and 0.65 MAC isofiurane (0.75 per cent end-expired); Group II was given 0.65 MAC nitrous oxide and 1-1.2 MAC influrane (1.2-1.4 per cent end-expired); Group III was given the same anaesthetic management as patients in Croup I but with the addition of fentanyl $\left(2 \mu \mathrm{g}^{-1}\right)$ before the skin incision and 's of the initial dose every 15 minutes during surgery: Group IV was treated as patients in Group / with an additional infusion of lidocaine $\left(30 \mu \mathrm{g} \cdot \mathrm{kg}^{-1} \cdot \mathrm{min}^{-1}\right)$; Groups V and VI were given $0.65 \mathrm{MAC}$ of nitrous oxide and fentanyl, 7.5 and $15 \mu g \cdot \mathrm{kg}^{-1}$, respectively, before skin incision with $\frac{1}{8}$ of the initial dose every 15 minutes during the operation; diazepam, $5 \mathrm{mg} / \mathrm{V}$ each hour of surgery, was given to prevent intraoperative awareness. Cortisol concentration was determined by radioimmunoassay method and

\section{Key words}

ANAESTHETIC TECHNIQUES: balanced, inhalation; ANAESTHETICS VOLATILE: isoflurane; ANAESTHETICS, LOCAL: lidocaine; COMPLICATIONS: stress

From the Departments of Anesthesiology and Medicine, The University of Alabama Medical Center, Birmingham, Alabama.

Address correspondence to: Dr. Simon Gelman, Department of Anesthesiology, The University of Alabama Medical Center, 619 South 19th Street, Birmingham, Alabama 35294. catecholamines were measured by high performance liquid gas chromatography in blood samples taken at different stages perioperatively.

All parients had sasisfactory haemodynamic courses of anaesthesia. Statistically significan increases in both epinephrine and norcpinephrine concentrations were observed during the immediate postoperative period in Group I patients only. Haemodynamic stabilin: wos maintained despite a no- to threefold increase in cortisol which occurred dirring the operation and intmediate postoperative period. More than I MAC of isofurane in conjunction with nitrous oxide (Gronp II) and fentanyl in a loading dose of $15 \mu \mathrm{g} \cdot \mathrm{kg}^{-1}$ (Group VI) did not show any advantages over other techuiques employed, but substantially delayed awakening and extubation.

An anaesthetic agent can be evaluated not only with regard to the influence on homeostasis per se, but also in tcrms of its ability to protect the organism from surgical stress. Responses to surgical trauma are largely mediated through the autonomic nervous system and adrenal medulla, and, therefore, are expressed as increases in heart rate (HR), blood pressure, and concentrations of stress associated substances in the circulation during and after surgery. Increases in cortisol and catecholamines are reliable indicators of surgical trauma and manifestations of the physiological response to stress. ${ }^{1,2}$ Different anaesthetics or combinations of different agents can provide different degrees of protection against similar surgical stress. The purpose of this study was to evaluate the ability of isoflurane, in 
combination with nitrous oxide, and both with and without lidocaine and fentanyl, to provide haemodynamic and hormonal stability during upper abdominal surgery.

Isoflurane anaesthesia in volunteers and surgically unstimulated patients was associated with a decrease in blood pressure and occasionally a decrease in HR. ${ }^{3-5}$ The addition of surgery was accompanied by an increase in HR; however, these results were observed in patients given isofurane in a relatively low dose. ${ }^{6}$ These data might be interpreled as evidence that light isoflurane anaesthesia does not sufficiently protect the cardiovascular system from surgical stress. Therefore, we chose two levels of isoflurane anaesthesia to examine the effect of isoflurane dose on response to surgery.

Infusion of local anaesthetics to supplement general anaesthesia has been used for many years. ${ }^{7,8}$ Lidocaine administered intravenously produced analgesia for experimentally induced pain and decreased MAC of inhalational agents. ${ }^{10-12} \mathrm{~A}$ plasma lidocaine concentration of $3.2 \mu \mathrm{g} \cdot \mathrm{m}]^{-1}$ during administration of 70 per cent nitrous oxide produced an anaesthetic effect equal to $1 \mathrm{MAC}^{12}$ Alterations in anaesthetic requirements induced by lidocaine could be related to blockade of nociceptive impulses at the level of spinal cord neurons. ${ }^{13}$ The combination of isoflurane with an infusion of lidocaine was used in this study in an attempt to further modify hormonal and haemodynamic responses to surgery.

Fentanyl in doses above $50 \mu \mathrm{g} \cdot \mathrm{kg}^{-114}$ and even as low as $10 \mu \mathrm{g} \cdot \mathrm{kg}^{-115}$ prevented catecholamine release during upper abdominal surgery. However, doses of $5 \mu \mathrm{g} \cdot \mathrm{kg}^{-1}$ of fentanyl did not prevent an increase in blood catecholamine concentration during laparotomy. ${ }^{16}$ Therefore, we chose fentany] doses of $2 \mu \mathrm{g} \cdot \mathrm{kg}^{-1}$ (combined with isoflurane and nitrous oxide), and 7.5 and $15 \mu \mathrm{g} \cdot \mathrm{kg}^{-1}$ (sup plemented by nitrous oxide only), to determine if one or more of these combinations would provide relatively effective protection from surgical stress without causing prolonged postoperative respiratory depression. Thus, the main hypothesis of the study can be formulated as follows: fentanyl and lidocaine supplementation to general anaesthesia with isoflurane and nitrous oxide permits a reduction in the dose of isoflurane and/or provides better protection against surgical stress than does isaflurane alone.

\section{Methods}

After approval from the Institutional Review Board on Human Research at The University of Alabama in Birmingham, informed consent was obtained from $60 \mathrm{ASA}$ physical status I-Il adult patients undergoing elective upper abdominal surgery (cholecystecomy, gastrectomy). All patients received the same premedication which consisted of diazepam, $0.15 \mathrm{mg} \cdot \mathrm{kg}^{-1}$ orally, and morphine, 0.1 $\mathrm{mg} \cdot \mathrm{kg}^{-1}$ intramuscularly and a standard induction with thiopentone, $4 \mathrm{mg} \cdot \mathrm{kg}^{-1}$. Endotracheal intubation was facilitated with $1.5 \mathrm{mg} \cdot \mathrm{kg}^{-1}$ of succinylcholine. Subsequent muscle relaxation was achieved with metocurine, $0.2-0.3 \mathrm{mg} \cdot \mathrm{kg}^{-1}$, titrated by train-of-four neuromuscular stimulation. The choice of metocurine was due to its minimal effect on cardiovascular function, compared with other muscle relaxants. ${ }^{17-19}$ In all patients ventilation was controlled with 0.65 MAC (66 per cent inspired) nitrous oxide in oxygen. Patients were randomly assigned to six groups, ten patients per group (Table I).

Patients in Group I received 66 per cent nitrous oxide and approximately $0.65 \mathrm{MAC}(0.75$ per cent end-expired) isoflurane to maintain blood pressure as close to pre-induction values as possible. Patients in Groups I, II, IHI, IV, V and VI received the same fluid management: lactated Ringer's solution was infused at a rate of $15 \mathrm{ml} \cdot \mathrm{kg}^{-1}$ during the first hour of laparotomy, $10 \mathrm{ml} \cdot \mathrm{kg}^{-1}$ during the second hour, and $8 \mathrm{ml} \cdot \mathrm{kg}^{-1}$ during the third and fourth hours. Blood loss was replaced with lactated Ringer's solution in a ratio of $1: 3$ and with an equal amount of blood when the hematocrit fell below 35 per cent.

Group Il patients received 66 per cent nitrous oxide and 1-1.2 MAC (1.15-1.35 per cent endexpired) of isoflurane. The amount of fluid given to

TABLE I Anaesthetic Management

\begin{tabular}{|c|c|}
\hline Groups & Angesthesia \\
\hline I & $\mathrm{N}_{2} \mathrm{O}-0.65 \mathrm{MAC}:$ Isothurane $-0.65 \mathrm{MAC}$ \\
\hline Il & $\mathrm{N}_{2} \mathrm{O}-0.65 \mathrm{MAC} ;$ Isoflurane $-1-1.2 \mathrm{MAC}$ \\
\hline III & $\begin{array}{c}\mathrm{N}_{2} \mathrm{O}-0.65 \mathrm{MAC} ; \text { Isoflurane } 0.65 \mathrm{MAC} \text {; Fentanyl } 2 \\
\mu \mathrm{g} \cdot \mathrm{kg}^{-1}+0.25 \mu \mathrm{g} \cdot \mathrm{kg}^{-1} / 15 \mathrm{~min}\end{array}$ \\
\hline IV & $\begin{array}{l}\mathrm{N}_{2} \mathrm{O}-0.65 \mathrm{MAC} \text {; Isoflurane } 0.65 \mathrm{MAC} \text {; Lidocaine } \\
\quad 1.5 \mathrm{mg} \cdot \mathrm{kg}^{-1}+30 \mathrm{Hg} \cdot \mathrm{kg}^{-1} / \mathrm{min}\end{array}$ \\
\hline $\mathrm{V}$ & $\begin{array}{c}\mathrm{N}_{2} \mathrm{O}-0.65 \mathrm{MAC} ; \text { Fentanyl } 7.5 \mu \mathrm{g} \cdot \mathrm{kg}^{-1}+\mathrm{I} \\
\mu \mathrm{g} \cdot \mathrm{kg}^{-1} / 15 \mathrm{~min} ; \text { Diazcpam } 5 \mathrm{mg} \cdot \mathrm{hr}^{-1}\end{array}$ \\
\hline V1 & $\begin{array}{c}\mathrm{N}_{2} \mathrm{O}-0.65 \mathrm{MAC} ; \text { Fentanyl } 15 \mu \mathrm{g} \cdot \mathrm{kg}^{-1}+2 \\
\mu \mathrm{g} \cdot \mathrm{kg}^{-1} / 15 \mathrm{~min} ; \text { Diazepam } 5 \mathrm{mg} \cdot \mathrm{hr}^{-1}\end{array}$ \\
\hline
\end{tabular}


patients in this group was increased by $1-21$ of lactated Ringer's solution to keep the blood pressure close to pre-induction values.

Group III patients received $2 \mu \mathrm{g} \cdot \mathrm{kg}^{-1}$ of fentanyl before the skin incision. One-eighth of the initial dose was given every 15 minules during surgery. They also reccived 66 per cent nitrous oxide and isoflurane, which was titrated to keep the blood pressure close to pre-induction values and was maintained at approximately 0.75 per cent endexpired.

Group IV patients received 66 per cent nitrous oxide, isoflurane, (about 0.75 per cent end-expired, titrated to keep blood pressure close to preinduction values) and a bolus of lidocaine, 1.5 $\mathrm{mg} \cdot \mathrm{kg}^{-1}$, before anaesthesia induction, with subsequent lidocaine infusion $\left(30 \mu \mathrm{g}^{\prime} \mathrm{kg}^{-1} \cdot \mathrm{min}^{-1}\right)$. The infusion was stopped at the end of the surgery. This technique should maintain a plasma level of about $3 \mu \mathrm{g} \cdot \mathrm{ml}^{-1}$ of lidocaine; ${ }^{20,21}$ however, we did not confirm this by measurement of plasma lidocaine.

Patients in Groups $V$ and VI received fentanyl, 7.5 and $15 \mu \mathrm{g} \cdot \mathrm{kg}^{-1}$, respectively before skir incision with $\frac{1}{8}$ of initial dose given every 15 minutes during surgery. The method of administration of fentanyl used in this study was based on a pharmacokinetic model of fentanyl derived from the data by McClain and Hug. ${ }^{22}$ The dosage of fentanyl should assure a relatively stable plasma level of fentanyl - not lower than $3.2 \mathrm{ng} \cdot \mathrm{ml}^{-1}$ when $15 \mu \mathrm{g} \cdot \mathrm{kg}^{-1}$ was the initial dose and not lower than $1.6 \mathrm{ng} \cdot \mathrm{ml}^{-1}$ when $7.5 \mu \mathrm{g} \cdot \mathrm{kg}^{-1}$ was used. ${ }^{23}$ Fentanyl was given in addition to 66 per cent of nitrous oxide. Diazepam, $5 \mathrm{mg}$ IV per each hour of surgery, was given to prevent intraoperative awareness.

In all patients, residual muscle paralysis was reversed at the end of the surgery with $2 \mathrm{mg}$ of atropine and $5 \mathrm{mg}$ neostigmine. Times of restoration of respiration and extubation, incidence of nausea, vomiting and emergence excitement were recorded. Extubation was performed when patients were awake and the following criteria met: forced vital capacity above $15 \mathrm{ml} \cdot \mathrm{kg}^{-1}$, negative inspiratory force greater than $30 \mathrm{mmHg}$, and a positive head-lift sign.

Cardiovascular variables - systolic, diastolic and mean blood pressure (using Dinamap Adult/Pediatric Vital Signs Monitor, Model 845XT, Criticon, Inc.) and HR - were monitored. End-expired isoflurane concentration was measured with an Engström Multigas Monitor for Anesthesia (EMMA). With at least a 30-minute warnup period, the EMMA was zeroed against room air. A humidity retaining device, "artificial nose," separated the EMMA sensor from the patient's humidified air. In this case, watcr vapour values consistently showed 0.5 per cent; therefore, the actual value of end-expired isoflurane concentration was equal to the read-off value minus 0.5 per cent. The EMMA was calibrated with a calibration transducer, provided by the Engström Company. Thirty random EMMA values were compared to measurements obtained with the Perkin-Elmer Medical Gas Analyzer, Model 1100 and found to be identical. Controlled ventilation was adjusted to maintain an end-expired carbon dioxide tension close to 40 $\mathrm{mmHg}$. Venous blood samples were taken to determine cortisol and catecholamine (epinephrine and norephinephrine) concentrations at the following seven stages: Stage I - one day prior to surgery, at 3-5 p.m. (baseline values), Stage II - before anaesthesia induction, at 7-9 a.m., Stage III inmediately after endotracheal intubation, Stage IV - 15 minutes after skin incision, Stage $V-I$ hour into surgical procedure, Stage VI and VII - two and six hours after surgery was completed, respectively.

Blood samples for analysis of catecholamines were collected in iced polystyrene tubes containing EDTA. After centrifugation, plasma was collected and stored at $-80^{\circ}$ for later analysis. Calecholamines were extracted one to two weeks later and then assayed by high performance liquid chromatography. ${ }^{24,26}$ Cortisol concentration in the plasma was determined using radioimmunoassay. ${ }^{27}$

Data analysis was computed by statistical analysis system (SAS) and consisted of determination of mean values of each variable at all stages. Differences between variables of groups and at different stages were determined with repeated measurements in time analysis of variance model. ${ }^{28}$ Since there is a large number of degrees of freedom ( 30 or $40)$ in the group by stage interaction term, truly significant differences could be diluted by a large number of non-significant differences resulting in an overall not significant group by stage interaction term. Thus regardless of whether the group by stage interaction term was significant, one way analysis of variances were run at each stage. Individual 
TABLE II Demographic data (Mcan \pm SE)

\begin{tabular}{lllll}
\hline Grotps & Age & BSA & \% Male & \% Cholecvstectomy \\
\hline l & $49 \pm 6$ & $1.77 \pm 0.07$ & $30 \pm 14$ & $80 \pm 13$ \\
II & $40 \pm 3$ & $1.91 \pm 0.06$ & $36 \pm 1.5$ & $82 \pm 12$ \\
III & $49 \pm 5$ & $1.80 \pm 0.04$ & $20 \pm 13$ & $80 \pm 13$ \\
IV & $38 \pm 5$ & $1.75 \pm 0.06$ & $0 \pm 0$ & $100 \pm 0$ \\
V & $48 \pm 4$ & $1.92 \pm 0.08$ & $18 \pm 12$ & $64 \pm 14$ \\
VI & $51 \pm 7$ & $1.79 \pm 0.05$ & $44 \pm 17$ & $56 \pm 17$ \\
\hline
\end{tabular}

See Table I for Group identification.

comparisons between group means was performed by Duncan's new multiple range test applied at each of the stage analyses. Within group comparisons utilized a two-way analysis of variance with one repeated factor (stage) and one independent factor (patient).

Comparisons of study demographics between groups for such variables as age and BSA was done by a one-way analysis of variance. Comparison of the proportions of each group that were of a given sex or had a particular surgical procedure was done by a chi square test of proportions. Sample size was determined arbitrarily and significance level equalled 0.05 .

\section{Results}

There were no statistically significant differences between the groups in age, sex, BSA, surgical procedures or duration of surgery (Table II). All patients were between 37 and 55 years and the duration of surgery varied between two and three hours.

Due to the design of the study, end-expired isoflurane concentration was higher in Group II compared with the other groups; however, there were no differences in end-expired isoflurane concentrations during surgery between Groups I, III and IV (Table III).

TABLE III End-expired isoflurane concentration (\%) during surgery (Mean $\pm S E$ )

\begin{tabular}{lll}
\hline Grosps & 15 min after skin incision & 1 hrof sicrgery \\
\hline I & $0.79 \pm 0.14$ & $0.66 \pm 0.10$ \\
II & $1.46 \pm 0.09 *$ & $1.25 \pm 0.07^{*}$ \\
III & $0.58 \pm 0.12$ & $0.65 \pm 0.16$ \\
IV & $0.74 \pm 0.12$ & $0.65 \pm 0.12$ \\
\hline
\end{tabular}

See Table 1 for Group identification. * ${ }^{*} p<0.05$ compared with Groups I. III and IV in corresponding stages (analysis of variance)
The analysis of HR showed a significant group by stage interaction. The other variables investigated (mean arterial blood pressure, plasma cortisol, epinephrine and norepinephrine) did not have a statistically interaction term. Changes in $\mathrm{HR}$ and mean arterial blood pressure (MAP) observed during surgery with all of the anaesthetic techniques employed, are presented in Table IV. Moderate, but statistically significant, decreases in HR were observed during surgery in patients who received fentanyl - Groups $V$ and VI.

A two- to three-fold increase in plasma cortisol levels occurred in all patients regardless of the anaesthetic technique employed (Table IV). The maximum increase was observed postoperarively at Stages VI and VII rather than during the surgical procedure itself. Rises in plasma cortisol values were similar in all anaesthetic groups.

Epinephrine and norepinephrine concentrations were increased during the immediate postoperative period in Group I patients (Table IV). There was a great inter-individual variability in plasma catecholamine levels which led to a relatively large standard deviation of the mean values at each stage of observation.

There were some differences in the inmediate postoperative course between the groups. Extubation after surgery was possible earlier in Groups I. III, and V than in Groups II, IV, and VI. There was a substantial delay in extubation in Group VI patients, who recejved relatively high doses fentanyl. The requirement for the first injections of analgesics was substantially delayed in patients who received fentanyl (Groups $V$ and VI - Table IV). Nausea occurred in two patients who received deep isoflurane (Group $\mathrm{II}$ ) and in one of the patients who received fentanyl (Group $V$ ), and vomiting occurred in only one of the patients in Group II (one of the patients who had nausea). Shivering, coughing, and/or excitement were not observed in any of the 60 patients.

\section{Discussion}

\section{Haemodynamics}

Certain changes in heart rate and blood pressure were obscrved in the various groups. Relatively deep isoflurane anaesthesia (Group II) was accompanied by a statistically significant increase in $\mathrm{HR}$ without concomilant decreases in blood pressure. 
TABLE IV Heart rale, mean arterial blood pressufe contisol and catecholanine concentrations (Mean \pm SE)

\begin{tabular}{|c|c|c|c|c|c|c|c|c|}
\hline \multirow[b]{2}{*}{ Groups } & \multirow[b]{2}{*}{ Variables } & \multirow[b]{2}{*}{ Baseline } & \multirow{2}{*}{$\begin{array}{l}\text { Before } \\
\text { induction }\end{array}$} & \multirow{2}{*}{$\begin{array}{l}\text { After } \\
\text { intubation }\end{array}$} & \multicolumn{2}{|l|}{ (during surgery) } & \multicolumn{2}{|l|}{ (after susgery') } \\
\hline & & & & & $15 \mathrm{~min}$ & $I H R$ & $2 H R$ & $6 H R$ \\
\hline \multirow[t]{5}{*}{1} & $\mathrm{HR}$ & $81 \pm 0.9$ & $84 \div 2.7$ & $84 \pm 4.0$ & $88=5.3$ & $86 \pm 5.6^{5.6}$ & $92+4.6^{\circ}$ & $88=3.2$ \\
\hline & MAP & $94 \pm 4.3$ & $102 \pm 2.6$ & $108=5.6$ & $102 \pm 7.6$ & $98 \pm 4.3$ & $100 \pm 5.1$ & $97 \pm 5.7$ \\
\hline & CORT & $5.5 \pm 0.8$ & $11.9 \pm 2.7$ & $1.3 .1=3.25$ & $19.50=2.50 *$ & $27.8 \pm 2.8^{*}$ & $35.1 \pm 4.8^{*}$ & $23.7=3.75^{*}$ \\
\hline & EPI & $134.4 \pm 33.7$ & $108.6 \pm 25.3$ & $177.0=70.9$ & $145.0=32.4$ & $178.0 \pm 39.6$ & $237.5 \pm 81.4$ & $467.6=192.2^{*}$ \\
\hline & NE & $251.4 \pm 69.9$ & $342.3 \pm 52.8$ & $368.8 \pm 60.5$ & $383.3=74.4$ & $32.3 .0 \pm 41.2$ & $419.5 \pm 101.4 \neq$ & $387.8=68.2^{*}$ \\
\hline \multirow[t]{5}{*}{ II } & HR & $78=2.2$ & $79 \pm 3.9$ & $95 \pm 3.4^{*}$ & $94 \pm 2.5 * 5.6$ & $95 \pm 4.7^{45,6}$ & $89 \pm 5.8^{\circ}$ & $87 \pm 4.6$ \\
\hline & MAP & $86 \pm 2.5$ & $94 \pm 2.2$ & $105 \pm 3.1^{*}$ & $99 \pm 6.0$ & $94 \pm 3.3^{6}$ & $95 \pm 3.0$ & $95 \pm 3.1$ \\
\hline & CORT & $7.7 \pm 0.8$ & $130=2.7$ & $12.9 \pm 2.0$ & $157 \pm 1.4$ & $22.2 \pm 2.3^{*}$ & $34.8 \pm 1.9^{*}$ & $33.5 \pm 5.6^{*}$ \\
\hline & EPI & $157.2 \pm .56 .2$ & $82.7 \pm 22.8$ & $245.4 \pm 114.9$ & $122.6=31.1$ & $118.0 \pm 44.9$ & $221.1 \pm 68.9$ & $136.2=15.9$ \\
\hline & NE. & $406.1 \pm 69.4$ & $207.6 \pm 32.1$ & $309.0 \pm 46.7$ & $406.2 \pm 82.8$ & $375.1 \pm 57.8$ & $347.8 \pm 43.5$ & $357.0 \pm 45.5$ \\
\hline \multirow[t]{5}{*}{ III } & $\mathrm{HR}$ & $81 \pm 2.7$ & $84 \pm 5.2$ & $89 \pm 6.3$ & $86 \pm 7.99$ & $88 \pm 6.0^{5.6}$ & $92 \pm 4.9^{\circ}$ & $88 \pm 3.8$ \\
\hline & MAP & $93 \pm 3.1$ & $95 \pm 4.8$ & $105 \pm 6.9$ & $109 \pm 5.5$ & $99 \pm 3.2$ & $98 \pm 4.8$ & $95 \pm 3.5$ \\
\hline & CORT & $11.9 \pm 1.8$ & $18.0 \pm 3.4$ & $16.0 \pm 2.2$ & $21.8 \pm 2.9^{*}$ & $35.1 \pm 3.3^{*}$ & $43.5 \pm 3.8^{*}$ & $46.9 \pm 3.3^{*}$ \\
\hline & EPI & $286.8 \pm 67.7$ & $146.0 \pm 57.1$ & $138.1 \pm 63.5$ & $251,6 \pm 68.2$ & $172.4 \pm 44.9$ & $184.3 \pm 33.8$ & $120.5 \pm 30.9$ \\
\hline & NE & $360.8 \pm 108.6$ & $277.0 \pm 47.5$ & $327.4 \pm 75.8$ & $475.7 \pm 83.9$ & $408.2 \pm 120.5$ & $397.0 \pm 70.5$ & $282.5 \pm 65.8$ \\
\hline \multirow[t]{5}{*}{ IV } & $\mathrm{HR}$ & $82 \pm 3.4$ & $84=7.2$ & $101 \pm 3.4^{5}$ & $89 \pm 6.0$ & $83 \pm 5.8^{5.6}$ & $89 \pm 4.6^{6}$ & $86 \pm 3.4$ \\
\hline & MAP & $91 \pm 4.2$ & $96 \pm 4.1$ & $116 \pm 4.5^{*}$ & $97 \pm 4.1$ & $95 \pm 4.4$ & $93 \pm 3.7$ & $95 \pm 4.8$ \\
\hline & CORT & $9.9 \pm 2.4$ & $14.1 \pm 2.2$ & $14.5 \pm 2.3$ & $23.0 \pm 1.0^{*}$ & $27.4 \pm 2.8^{*}$ & $32.2 \pm 3.2^{*}$ & $31.9 \pm 2.4^{*}$ \\
\hline & EPI & $45.0 \pm 17.1$ & $43.2 \pm 9.9$ & $44.0 \pm 10.4$ & $59.7 \pm 29.4$ & $63.8 \pm 32.4$ & $104.4 \pm 33.7$ & $140.0 \pm 45.0$ \\
\hline & NE & $355.6 \pm 99.4$ & $222.8 \pm 54.1$ & $316.8 \pm 114.0$ & $262.5 \pm 46.4$ & $382.4 \pm 112.8$ & $332.2 \pm 49.9$ & $399.5 \pm 146.5$ \\
\hline \multirow[t]{5}{*}{ v } & HR & $79 \pm 3.7$ & $74 \pm 4.8$ & $79 \pm 8.1^{4}$ & $73 \pm 3.4^{7}$ & $68 \pm 3.6^{* 1-4}$ & $78 \pm 4.3$ & $81 \pm 4.4$ \\
\hline & $\mathrm{MAP}$ & $91 \pm 3.5$ & $98 \pm 4,1$ & $104 \pm 7.8$ & $104 \pm 5.1$ & $106 \pm 4.2 *$ & $101 \pm 4.5$ & $94 \pm 4.2$ \\
\hline & CORT & $11.7 \pm 1.8$ & $10.9 \pm 2.0$ & $10.8 \pm 2.3$ & $14.7 \pm 2.6$ & $22.1 \pm 3.2^{*}$ & $34.6 \pm 3.7^{*}$ & $29.7 \pm 2.4^{*}$ \\
\hline & EPI & $129.5 \pm 23.8$ & $48.2 \pm 14.5$ & $78.5 \pm 29.3$ & $165.0 \pm 48.5$ & $128.4 \pm 40.3$ & $188.8 \pm 60.3$ & $148.4 \pm 79.8$ \\
\hline & $\mathrm{NE}$ & $205.5 \pm 56.2$ & $268.4 \pm 64.6$ & $163.6 \pm 20.5^{6}$ & $297.2 \pm 57.3$ & $263.5 \pm 56.5$ & $338.4 \pm 93.8$ & $275.0 \pm 93.7$ \\
\hline \multirow[t]{5}{*}{ VI } & HR & $79 \pm 2,2$ & $81=3.8$ & $8.5 \pm 4.2$ & $76 \pm 4.3^{2}$ & $67 \pm 2.6^{* 1-4}$ & $75 \pm 3.0^{1-4}$ & $80 \pm 2.1$ \\
\hline & MAP & $95 \pm 3.6$ & $97 \pm 5.1$ & $103+7.1$ & $112 \pm 7.9$ & $109 \pm 4.1^{2}$ & $100 \pm 3.1$ & $98 \pm 2.9$ \\
\hline & CORT & $12.0 \pm 1.0$ & $14.8 \pm 2.3$ & $12.4 \pm 1.9$ & $14.7 \pm 1.5$ & $25.2=3.2^{*}$ & $34.1 \pm 10.2^{*}$ & $33.4 \pm 4.6^{*}$ \\
\hline & EPI & $220.0 \pm 48.7$ & $119.1 \pm 24.2$ & $130.6 \pm 35.2$ & $207.1 \pm 96.0$ & $105.6 \pm 21.3$ & $107.5 \pm 27.1$ & $232.0 \pm 20.9$ \\
\hline & NE & $344.0 \pm 64.2$ & $406.2 \pm 50.7$ & $372.6 \pm 70.7^{5}$ & $268.7 \pm 50.2$ & $348.1 \pm 70.0$ & $452.0 \pm 112.1$ & $361.0 \pm 82.6$ \\
\hline
\end{tabular}

See Table I for Group identification. HR = heart rate (beats per minute); MAP = mean arterial pressure (nmHg); CORT = contisol $\left(\left.\mu \mathrm{g} \cdot \mathrm{d}\right|^{-1}\right) ; \mathrm{EPI}$ and $\mathrm{NE}=$ epinephrine and norephrine, $\left(\mathrm{pg} \cdot \mathrm{ml}^{-1}\right) *=\mathrm{p}<0.05$ compared with baseline values within the sane group ${ }^{1-3}$ etc. $p<0.05$ compared with corresponding stages of Groups 1. II. III etc.

Such an increase in HR did not occur in the three other groups which recejved isoflurane (Group I, III and IV). The moderate tachycardia observed during surgery in Group Il patients could be related to a deeper depression of vagal activity compared with the depression of sympathetic activity. ${ }^{29}$ Isoflurane and nitrous oxide (0.65 MAC each) alone or in conjunction with low dose fentanyl or lidocaine provided stable cardiac rhythm and blood pressure during the surgical procedure (Groups I, III and IV). The combination of isoflurane with a small dose of fentanyl (Group III) was not accompanied by a decrease in blood pressure. Such a decrease was observed when small doses of fentanyl were used with halothane. ${ }^{30}$

Patients receiving different doses of fentanyl (Groups V and VI), experienced a moderate decrease in HR during surgery (one hour after skin incision) compared with baseline values and values observed during corresponding stage in the other four groups. These changes were minor and did not present any problems to any of the patients. On the contrary, these alterations may confer an advantage to patients with ischaemic heart disease: an increase 
TABLE $V$ Time (min) of extubation and first usage of analgesics (Mean \pm SE)

\begin{tabular}{lcc}
\hline Groups & Time of extubution & Time of lst ustge of anaigesics \\
\hline I & $17 \pm 5.4^{2.6}$ & $67 \pm 13.5^{5.6}$ \\
II & $53 \pm 20.1^{1.0}$ & $120 \pm 25.0^{6}$ \\
III & $21 \pm 10.9^{6}$ & $57 \pm 22.7^{5.6}$ \\
IV & $52 \pm 25.6$ & $81+26.5^{6}$ \\
V & $32 \pm 16.5^{6}$ & $175 \pm 58.4^{1.3}$ \\
VI & $161 \pm 67.9^{1-3.5}$ & $326 \pm 56.5^{1-4}$ \\
\hline
\end{tabular}

See Table 1 for Group identification. ${ }^{1,2.3}$ etc. $=p<0.05$ different from Groups l, II, II] etc, respectively (analysis of variance),

in time of diastole would improve myocardial blood supply.

\section{Hormonal Changes}

Statistically significant increases in both epinephrine and norepinephrine concentrations were observed during the immediate postoperative period in Group I patients only (Table IV). This might mean that anaesthetic techniques employed in the remaining five groups modified the catecholamine response to surgical stress. Catecholamine release during laparotomy was prevented with more than $10 \mu \mathrm{g}^{\circ} \mathrm{kg}^{-1}$ of fentanyl ${ }^{14.15}$ but was not blocked by $5 \mu \mathrm{g} \cdot \mathrm{kg}^{-1}$ of fentanyl. ${ }^{16}$ Our data have confirmed these observations and, moreover, have shown that a loading dose of fentanyl larger than 7.5 $\mu \mathrm{g} \mathrm{kg}^{-l}$ (in conjunction with nitrous oxide) is also able to modify sympatho-adrenal response to laparotomy. The same seems to be true for some other anaesthetic techniques used in the study: deep isoflurane anaesthesia and/or supplementation of isoflurane $(0.65 \mathrm{MAC})$ with nitrous oxide and small doses of fentanyl $\left(2 \mu \mathrm{g} \cdot \mathrm{kg}^{-1}\right)$ or infusion of lidocaine $\left(30 \mu \mathrm{g} \cdot \mathrm{kg}^{-1} \cdot \mathrm{min}^{-1}\right)$.

Baseline values of plasma epinephrine in our patients were somewhat increased when compared with other reports. ${ }^{31,32}$ This was probably related to the psychological stress response to upcoming surgery and/or to venipuncture used for the collection of the first blood sample (all following samples were taken through indwelling cannulas). Well known diumal variation in cortisol and catecholamine concentrations may have contributed to the large variability in the values observed throughout the perioperative course.

Cortisol level was increased during surgery in all patients regardless of the anaesthetic technique employed. This increase was greater during the immediate postoperative period than during the surgical procedure. Some authors have noted that it is somewhat easier to block the release of catecholamines than cortisol during surgery. ${ }^{33}$

\section{Clinical Course}

By chance, the random assignment process led to no male patients in Group IV. However, there was not a statistically significant difference in the percentage of males between groups, and we do not believe that the absence of males in this group influenced the results of the study.

Both fentanyl and lidocaine have been shown to decrease MAC requirements (move response to skin incision) of inhalational agents. ${ }^{10-12.34}$ They did not, however, reduce isoflurane requirements to control MAP, HR or affect cortisol release (Table IV).

The earliest awakening and extubation occurred in Groups I, III and V, while this time was substantially prolonged in Group VI patients who received relatively high doses of fentanyl (15 $\mu \mathrm{g} \cdot \mathrm{kg}^{-1}$ ). Patjents who received fentanyl (Groups $\mathrm{V}$ and $\mathrm{VI}$ ) did not require postoperative analgesia for a much longer period of time than patients who received isoflurane anaesthesia alone or in any employed combination. These results are not surprising and can be considered as small and probably unimportant advantages or disadvantages of one technique over another. However, it is interesting to note that small doses of fentanyl $\left(7.5 \mu \mathrm{g} \cdot \mathrm{kg}^{-1}\right.$ Group V) allowed carly awakening and extubation, and still provided a longer postoperative analgesia than isoflurane. Doubling the dose of fentanyl was not accompanied by any benefits and, on the contrary, led to undesirable postoperative respiratory depression. The study illustrates that stable haemodynamics and satisfactory clinical course of anaesthesia can be provided by titration of anaesthetic or a combination of several agents; the agent(s) per se might play a secondary role.

In conclusion, isoflurane anaesthesia, $0.65 \mathrm{MAC}$ (in conjunction with 66 per cent nitrous oxide), alone or in combination with small doses of fentanyl $\left(2 \mu \mathrm{g} \cdot \mathrm{kg}^{-1}\right)$, or lidocaine $\left(30 \mu \mathrm{g} \cdot \mathrm{kg}^{-1} \cdot \mathrm{min}^{-1}\right)$, as well as fentanyl in doses of 7.5 and $15 \mu \mathrm{g} \cdot \mathrm{kg}^{-1}$ (in conjunction with nitrous oxide), assured a stable and steady haemodynamic course of anaesthesia during upper abdominal surgery. Deeper isoflurane anaesthesia (more than 1 MAC in conjunction with 
nitrous oxide) did not have any advantages over the other techniques employed. The larger dose of fentanyl ( $\left.15 \mu \mathrm{g} \cdot \mathrm{kg}^{-1}\right)$ did not have any advantages over a smaller dose $\left(7.5 \mu \mathrm{g} \cdot \mathrm{kg}^{-1}\right)$; however, it did cause a substantial delay in awakening and extubation.

\section{Acknowledgements}

The authors are thankful to J.G. Reves, MD for his valuable comments and also to Ohio Medical Anesthetics Company for supporting the study.

\section{References}

I Selye $H$. Stress in Health and Disease. London: Butterworths, 1976

2 Oyama $T$. Endocrine responses to anesthetic agents. Br J Anacsth 1973; 45: 275-81.

3 Linde $H W$, Oh, SO, Homi J, Joshi C. Cardiovascular effects of isoflurane and halothane during controlled ventilation in older patients. Anesth Anale 1975; 54: 701-4.

4 Mallow JE, Whire RD, Cucchiara RF, Tarhan S. Hemodynamic effects of isoflurane and halothane in patients with coronary artery disease. Anesth Analg 1976; 55: 135-8.

5 Tarnow J, Bruckner JB, Eberlein HJ, Hess W, Patschke D. Hacmodynamics and myocardial oxygen consumption during isoflurane (Forane) anaesthesia in geriatric patients. Br J Anaesth 1976; 48: 669-75.

6 Graves $C L, M C D e r m o t$ RW. Bidwai A. Cardiovascular effects of isoflurane in surgical putients. Anesthesiology 1974; 41: 486-9.

7 Steinhaus JE. Supplementation of $\mathrm{N}_{2} \mathrm{O}$ anesthesia and intravenous lidocaine. Ir: Eastwood DW, cd. Nitrous Oxide. Philadelphia: FA Davis, 1964; 89-95.

8 Quasha AL, Eger EI II, Tinker JH. Determination and applications of MAC. Anesthesiology 1980; 53: 315-34.

9 Rowlingson JC, DiFazio CA, Foster J, Carron H. Lidocaine as an analgesic for experimental pain. Anesthesiology 1980; 52: 20-2.

10 Himes RS Jr. DiFazio CA, Burney RG. Effects of lidocaine on the anesthetic requirements for nitrous oxide and halothane. Anesthesiology 1977; 47: 437-40.

11 Himes RS Jr, Munson ES, Embro JW. Enflurane requirement and ventilatory response to carbon dioxide during lidocaine infusion in dogs. Anesthesiol ogy $1979 ; 51: 131-4$.
12 Difazio CA, Burney RG, Himes RS Jr. Alterations in general anesthetic requirements with lidocaine. Abstract of Scientific Papers 1976 Annual Meeting of Amcrican Society of Ancsthesiologists, San Francisco, California. 1976; 513-4.

13 Dohi S, Kitahata LM, Toyooka H, Ohtani M, Namiki $A, T a u b A$. An analgesic action of intravenously administered lidocaine on dorsal-horn neurons responding to noxious thermal stimulation. Anesthesiology 1979; 51: 123-6.

14 Hall $G M$, Young C, Holdcroft A, Alaghband-Zadeh J. Substrate mobilisation during surgery. $A$ comparison between halothane and fentanyl anacsthesia. Anaesthesia 1978; 33: 924-30.

15 Parikh RK, Naismith Sewnauth D, Campbell BC. Reid $I L$. Comparison of halothane and fentanyl sup. plementation to general anaesthesia on the stress response of patients undergoing upper abdominal surgery. Br J Anaesth 1982; 54: 231

16 Brown FF III, Owens WD. Fells JA, Spitznagel EL, $C r y e r P E$. Plasma epinephrine and norepinephrine levels during anesthesia: Enflurane- $\mathrm{N}_{2} \mathrm{O}-\mathrm{O}_{2}$ compared with fentanyl- $\mathrm{N}_{2} \mathrm{O}-\mathrm{O}_{2}$. Anesth Analg 1982; 61: 366-70.

17 Stoelting $R G$. Hemodynamic effects of dimethyltubocurarine during nitrous oxide - halothane anesthesia. Anesth Analg 1974; 53: 513-5.

18 Savarese IJ, Ali HH, Antonio RP. The clinical pharmacology of metocurine: dimethyltubocurarinc revisited. Anesthesiology 1977; 47: 277-84.

19 Stanley $T H$. Cardiovascular effects of metocurine during enflurane anesthesia in man. Anesth Analg 1978; 57: 540-3.

20. LeLorier J, Grenon D, Latour Y et al. Pharmacokinetics of lidocaine after prolonged intravenous infusions in uncomplicated myocardial infaretion. Ann Intern Med 1977; 87: 700-2.

21 Ochs $H R$. Carstens $G$, Greenblatt DJ. Reduction of lidocaine clearance during continuous infusion and by co-administration of propranolol. N Eng J Med 1980; 303: 373-7.

22 McClain DA, Hug CC Jr. Intravenous fentanyl kinetics. J Clin Pharmacol Ther 1980; 106-14.

23 Reves $J G$, Greene ER Jr, MacKrell TN. Continuous infusion of intravenous anesthetics: Automated i.v. anesthesia, a rational method of drug administration. In: Stanlcy TH, Petty WC eds. New anesthetics agents, devices and monitoring techniques. Boston: Martinus Nijhoff, 1976: 192-204.

24 Wang $M E$. Imai $K$, Yoshioka $M$. Tamura $Z$. Gasliquid chromatographic and mass fragmentographic 
detcrmination of catecholamines in human plasma. Clinca Chimica Acta 1975; 63: $13-9$.

25 Hjemdahl P, Daleshog $M$, Kahan $T$. Deternination of plasma catecholamines by high perfornance liquid chromatography with electrochemical detection: comparison with a radioenzymatic method. Life Sci 1979; $25: 131-8$

26 Davis GC, Kissinger PT. Strategies for determination of serum or plasma norepinephrine by reverse phase liquid chromatography. Anal Chem 1981; 53: $156-9$.

27 Yaluw RS, Berson SA. Introduction and general considerations, in: Odell WD, Daughaday WH, cds. Principles of competitive protein hinding assays, Philadelphia: JB Lippincott, 1971: 1-24.

28 Snedecor GW, Cochran WG. Statistical methods, 7 th ed. Ames, lowa: lowa State University Piess, 1980: 385 .

29 Skovsted $P$, Sapthavichaikul $S$. The effects of isofurane on arterial pressure, pulse rate, autonomic nervous activity and barostatic reflexes. Can Anaesth Soc J 1977: 24: 304-17.

30 Sebet PS, Bovill JG, Schellekens APM, Hawker CD. Hormonal responses to high-dose fentanyl anacsthesia. Br J Anacsth 1981; 53: 941-7.

31 Robertion D, Johnson GA, Robertsen RM, Nies AS, Shand DG, Oates JA. Comparative assessment of stimuli that release neuronat and adrenomedullary catechomamines in man. Circulation 1979;59: 637-43.

32 Wallace $R$, Karp RB, Reves JG, Oparil S. Smith $L R$, James $T N$. Pathogenesis of paroxysmal hypertension developing during and after coronary bypass surgery: a study of hemodynamic and humoral facturs. Am J Cardiol 1980; 46: 559-65.

33 Abrums L, Griepp R, Ergin A, Matswoka M. Haemodynarnics of halothane anaesthesia plus fentanyl. Can Anaesth Soc J 1982; 29: 505-6.

34 Murphy MR, Hug CC. The anesthetic potency of fentanyl in terms of its reduction of enflurane MAC. Anesthesiology 1982; 57; 485-8.

\section{Résumé}

Cette étude compare le degré de protection contre le stress chirurgial apporté par diverses approches anesthésiques. Soixamte patients répartis en six groupes de dix ont été étudiés au cours de laparotomie. Les terhniques anesthesiques on té les swivontes: Groupe l: protoryde d'azote 0.65 MAC (66 pour cent du mélange inspiré) et isofurane $0.65 \mathrm{MAC}(0.75$ pour cent en find' expiration $)$.

Groupe II: protoxyde d'azote 0.65 MAC el isoflurane 1-1.2 MAC (1.2 a 1.4 pour cent en fin d'expiration).

Groupe III: les mêmes concentrations que le groupe! avec addition de fentanyl $\left(2 \mu \mathrm{g} \cdot \mathrm{kg}^{-1}\right.$ ) an'ant l' incivion de la peau et le huitieme de cette dose aur 15 minures duram la chirurgie.

Groupe IV: même concentration inspirée que pour les patients da groupe I avec infusion additionnelle de lidocaine $\left(30 \mu \mathrm{g}^{\mathrm{kg}} \mathrm{g}^{-1} / \mathrm{minute}\right)$.

Groupes V el VI: protoxyde d'azote 0.65 MAC ef fentanyl 7.5 et $15 \mu \mathrm{g} \cdot \mathrm{kg}^{-1}$ respectivement avant l'incision de la peau er ensuitc le hutrième de ces doses initiale; aux 15 minutes durant l'intervention. $5 \mathrm{mg}$ i.t. rle diazépan a été administré à toutes les houtres durant l'opération afin d'empêcher la prise de conscience peropératoire.

Les concentrations de cartisol ont étê mesurées par la méthade de titrage radio immunologique et les catecholamines par chromatographie en phase gazeuse sur des échantillons de sang pris aux différentes étupes de l'étude. Pour lous les groupes, la rechnique choisie a maintenu une siabilité hémodynamique sarisfaisume durant la chirurgie. Seuls les patients du groupe I ont montré une élévation statistiquement significative des concentrations d'épinéphrine et de norépinéphrine à lat période post-opératoire immédiate (deut heures apres la fin de l'interventionj. La stabilité hémodynamique s"est maistenue malgré Iaugmentation du cortisol qui a doublé ou méme triplé pendant l' intervention et durant la période post-opératoire immédiate. Les associations d'isofiurane I MAC avec protoxyde d' azote (groupe II) et isofurane $1 \mathrm{MAC}$, protoxyde d' azole el fentanyl en dose d'amorce de $15 \mu \mathrm{g} \cdot \mathrm{kg}^{-1}$ (groupe VI) he semblent pas présenter d'avantages sur les autres techniques employées et ont contribué à retarder le réveil et le montent de l'exubation. 